\title{
AKTIVITAS METABOLISME BEBERAPA KLON KARET PADA BERBAGAI FREKUENSI SADAP DAN STIMULASI
}

\author{
Metabolic Activity of Several Rubber Clones at Different \\ Tapping Frequencies and Stimulation \\ Eva HERLINAWATI dan KUSWANHADI \\ Balai Penelitian Sembawa, Pusat Penelitian Karet \\ Jalan Raya Palembang P. Balai KM 29, PO BOX 1127 Palembang 30001 \\ Email : eva_herlinawati@yahoo.com
}

Diterima tanggal 15 Mei 2013 / Disetujui tanggal 13 September 2013

\begin{abstract}
Stimulation is an important part in the exploitation system of rubber trees to increase production. The emergence of many clones requires knowledge of the relationship between the production of latex and physiological conditions to optimize stimulation, thus the exploitation systems applied are not over or under exploitation. The purpose of this study was to compare the metabolic activity of $P B$ 260, RRIM 600 and $P B 217$ clones at various tapping frequencies and stimulation. The experiment was carried out in the experimental field of Sembawa Research Centre from April 2010 until March 2012. The experimental design was a completely randomized block design with five tapping systems and three replications. The experiment used PB 260, RRIM 600, and PB 217 clones planted in 2004. The results showed that the quick starter clones with low sucrose content and high inorganic phosphorous such as PB 260 , only required wounding to activate cell metabolism. Also, it did not need stimulation with high frequency to increase production. The function of stimulation in quick starter clones reduce the latexflow disturbance, whereas RRIM 600 and PB 217 clones required stimulation to activate cell metabolism. Optimum frequencies of stimulation for RRIM 600 and PB 217 clones were 12/y and $24 / y$, respectively.
\end{abstract}

Keywords: Hevea brasiliensis, clone, tapping system, ethephon, production, physiological conditions

\footnotetext{
Abstrak

Stimulasi merupakan bagian penting dalam sistem eksploitasi tanaman karet untuk meningkatkan produksi. Munculnya banyak klon menuntut pengetahuan mengenai hubungan antara produksi lateks dengan kondisi fisiologis tanaman untuk mengoptimalkan penggunaan stimulan, sehingga sistem eksploitasi yang diterapkan tidak mengalami over atau under eksploitasi. Penelitian ini bertujuan untuk membandingkan metabolisme klon PB 260, RRIM 600 , dan PB 217 pada berbagai frekuensi sadap
}

maupun stimulasi. Penelitian dilaksanakan di Kebun Percobaan Balai Penelitian Sembawa mulai April 2010 sampai Maret 2012 dengan Rancangan Acak Kelompok dengan 5 perlakuan sistem sadap dan 3 ulangan, menggunakan klon PB 260, RRIM 600, dan PB 217 tahun tanam 2004. Hasil penelitian menunjukkan klon berproduksi tinggi (quick starter) dengan kandungan sukrosa rendah dan fosfat anorganik tinggi seperti PB 260, hanya membutuhkan pelukaan (wounding) untuk mengaktifkan metabolisme sel lateks, tidak membutuhkan stimulan dengan frekuensi yang tinggi untuk meningkatkan produksi. Stimulasi pada klon berproduksi tinggi hanya berfungsi untuk mengurangi adanya hambatan aliran. Sementara klon RRIM 600 dan PB 217 membutuhkan stimulan untuk mengaktifkan metabolisme sel lateks. Frekuensi stimulasi optimal untuk RRIM 600 dan PB 217 masing-masing adalah 12/y dan $24 / y$.

Katakunci: Hevea brasilinsis, klon, sistem sadap, etefon, produksi, kondisi fisiologis

\section{PENDAHULUAN}

Tujuan utama budidaya tanaman karet adalah untuk memaksimalkan keuntungan dalam satu siklus pertanaman. Kondisi tersebut dapat tercapai jika tanaman karet sehat dan penyadapan dilakukan sesuai dengan norma sadap. Keuntungan maksimum dapat dicapai dengan jalan meningkatkan produktivitas tanaman atau mengurangi biaya dari suatu sistem eksploitasi (Junaidi et al., 1990).

Pemakaian stimulan merupakan bagian integral dari sistem eksploitasi karet terutama pada perkebunan besar untuk mencapai keuntungan yang maksimal. Namun berdasarkan penelitian telah diketahui bahwa penggunaan stimulan 
harus dikombinasikan dengan penurunan intensitas sadap, yaitu dengan penurunan frekuensi sadap, dari d2 menjadi d3 atau d4 untuk menjaga kesehatan tanaman (Junaidi et al., 1990). Oleh sebab itu, penggunaan stimulan juga dapat mengurangi kebutuhan tenaga kerja dan mengatasi masalah ketersediaan tenaga yang terampil.

Pada beberapa klon Hevea brasiliensis, stimulan dapat meningkatkan produksi lateks dengan memperlama aliran lateks dan mengaktifkan metabolisme sel lateks (Tungngoen et al., 2009). d'Auzac dan Jacob (1984) dan Gohet et al., (2008) melaporkan bahwa kemampuan fisiologis tanaman untuk menghasilkan lateks tampak pada kandungan sukrosa, fosfat anorganik, tiol, dan kadar karet kering (KKK) dalam lateks. Silpi et al., (2006) menyatakan bahwa stimulan etefon mempengaruhi keseimbangan sukrosa dalam pembentukan lateks dan juga meningkatkan aktivitas metabolisme. Di samping itu stimulan etefon juga memiliki peran dalam mendorong pertukaran air sehingga menurunkan hambatan aliran, yang berakibat kadar karet kering menurun (Jacob et al., 1989).

Penelitian ini bertujuan untuk membandingkan aktivitas metabolisme klon PB 260, RRIM 600, dan PB 217 pada berbagai frekuensi sadap maupun frekuensi stimulasi. Frekuensi sadap dan stimulasi yang tepat dan optimum diperoleh dari produksi tertinggi pada masing-masing klon, tanpa menimbulkan efek negatif terhadap metabolisme dalam sel lateks.

\section{BAHAN DAN METODE}

Penelitian dilaksanakan di Kebun Percobaan Balai Penelitian Sembawa mulai April 2010 sampai Maret 2012. Percobaan disusun berdasarkan Rancangan Acak Kelompok dengan 5 perlakuan sistem sadap dan 3 ulangan. Percobaan menggunakan klon PB 260, RRIM 600, dan PB 217 tahun tanam 2004 yang ditanam dengan jarak tanam $6 \mathrm{~m} \times 3 \mathrm{~m}$. Perlakuan untuk masingmasing klon adalah sebagai berikut :

1. $\mathrm{S} / 2 \mathrm{~d} 1$

2. $\mathrm{S} / 2 \mathrm{~d} 2$

3. $\mathrm{S} / 2 \mathrm{~d} 4$

4. $\mathrm{S} / 2 \mathrm{~d} 4 \mathrm{ET} 2,5 \% \mathrm{Ga} 1,012 / \mathrm{y}(\mathrm{m})$

5. S/2 d4 ET2,5\% Ga 1,0 24/y (2w)
Pengamatan dilakukan terhadap peubah produksi, kadar karet kering lateks, kadar sukrosa, kadar fosfat anorganik, kadar tiol, dan intensitas kering alur sadap. Pengamatan produksi dilakukan setiap hari sadap, sedangkan kering alur sadap setiap 3 bulan. Pengambilan sampel lateks untuk diagnosis lateks dilakukan setiap bulan.

Produksi karet ditimbang sebagai lump mangkok. Kadar karet kering (KKK) lateks diukur dengan metode gravimetri, berdasarkan perbandingan \% bobot kering dengan bobot basah lateks sebanyak 5 gram. Pengeringan dilakukan dengan oven suhu $100^{\circ} \mathrm{C}$ hingga bobotnya tetap.

Kadar sukrosa, fosfat anorganik, dan tiol diukur di laboratorium dengan menggunakan spektrofotometer, masingmasing absorbansi diukur pada panjang gelombang 627, 750, dan $412 \mathrm{~nm}$. Setiap sampel lateks $(1 \mathrm{ml})$ diambil dan dipreparasi ke dalam $9 \mathrm{ml}$ TCA 2,5\% (asam trikloro asetat) menjadi serum TCA. Pengukuran kadar sukrosa lateks menggunakan metode Anthrone (Dische, 1962). Kadar fosfat anorganik berdasarkan pengikatan oleh ammonium molibdat yang kemudian tereduksi oleh $\mathrm{FeSO}_{4}$ dalam reaksi asam (Taussky dan Shorr, 1953). Kadar tiol diukur berdasarkan prinsip reaksinya dengan asam dithiobisnitrobenzoat (DTNB) yang membentuk TNB yang berwarna kuning (McMullen, 1960).

Pengamatan persentase kering alur sadap (KAS) dilakukan secara visual, kemudian diubah dengan penilaian skor sebagai berikut:

$0=$ tidak terjadi KAS

$1=1-25 \%$ alur sadap kering

$2=26-50 \%$ alur sadap kering

$3=51-75 \%$ alur sadap kering

$4=76-100 \%$ alur sadap kering

\section{HASIL DAN PEMBAHASAN}

\section{Pengaruh Frekuensi Sadap}

Klon PB 260 sangat respons terhadap frekuensi sadap, yaitu adanya peningkatan produksi sebesar $158,6 \%$ dengan penurunan frekuensi sadap dari d 1 menjadi d4 (Gambar 1). Sementara klon RRIM 600 dan PB 217 kurang respons terhadap 
perbedaan frekuensi sadap dibanding PB 260. Penurunan frekuensi sadap dari $d 1$ menjadi d4 pada klon RRIM 600 dan PB 217 hanya meningkatkan produksi sebesar $20,7 \%$ dan $70,6 \%$.

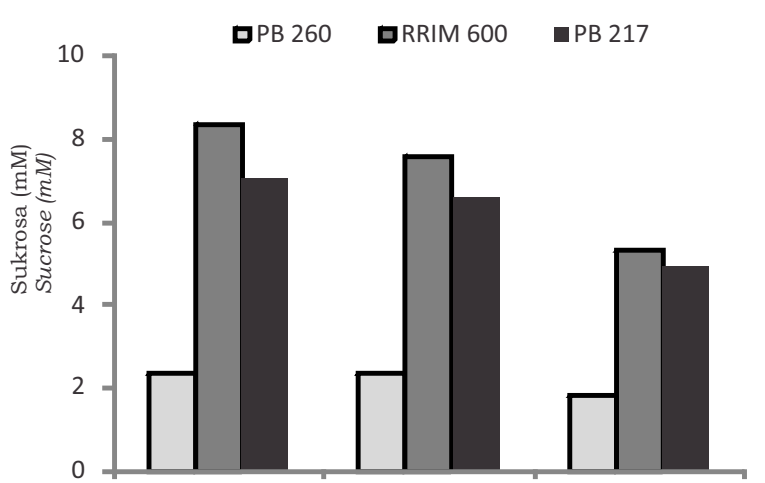

d1

Frekuensi sadap

Tapping frequency

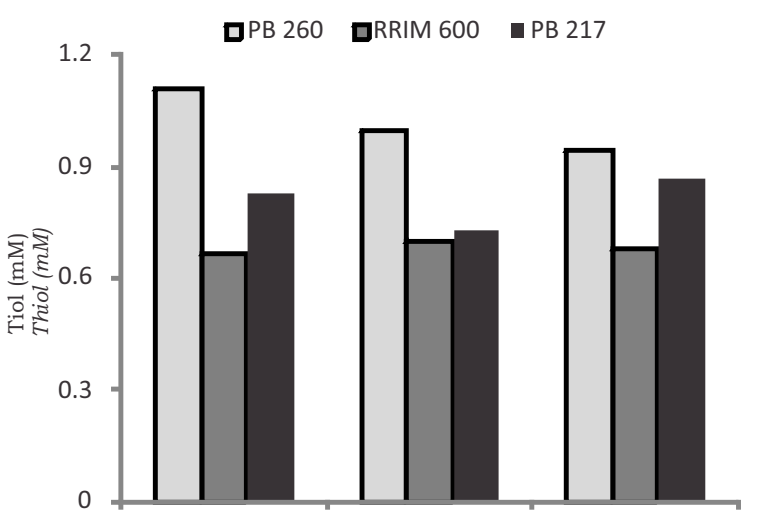

d1

Frekuensi sadap Tapping frequency d2

\begin{abstract}
d2
\end{abstract}
d4

d4

ㅁB 260

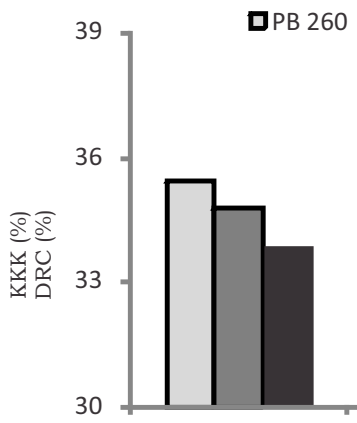

d1
Penurunan frekuensi sadap pada klon PB 260 sedikit menurunkan kandungan sukrosa, namun tidak mempengaruhi kandungan fosfat anorganik dan tiol. Pada klon RRIM 600 dan PB 217, penurunan frekuensi sadap menurunkan kandungan

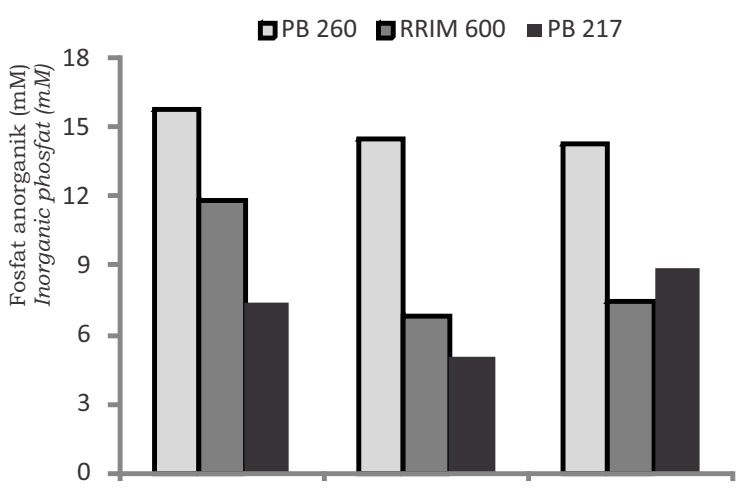

d1

d2

Frekuensi sadap Tapping frequency

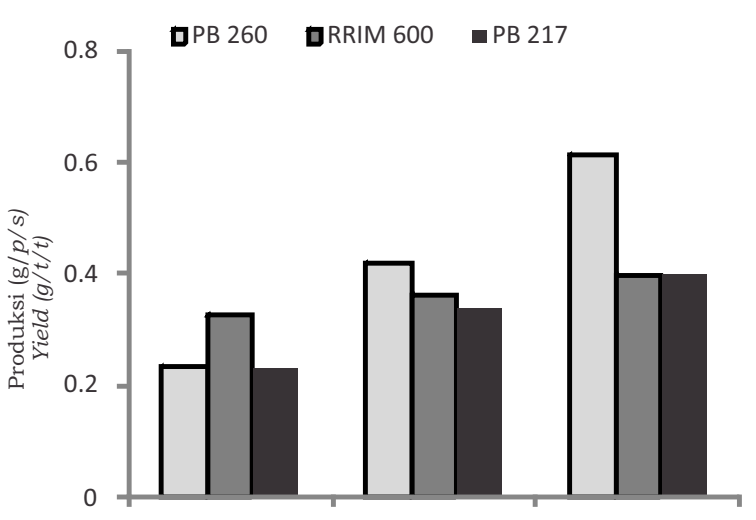

d1

d2

d4

d4

$$
\text { Frekuensi sadap }
$$

Tapping frequency 
sukrosa dan fosfat anorganik, dengan kandungan tiol yang tidak terpengaruh. Kandungan sukrosa PB 260 paling rendah dibanding RRIM 600 dan PB 217, namun PB 260 memiliki kandungan fosfat anorganik dan tiol yang lebih tinggi.

Penurunan frekuensi sadap pada klon PB 260 (d1 menjadi d4) mampu meningkatkan produksi dengan status kandungan sukrosa yang rendah dan fosfat anorganik yang tinggi. Kondisi tersebut mengindikasikan bahwa klon PB 260 dengan pelukaan (wounding) saja sudah cukup mengaktifkan metabolisme sel lateks untuk menghasilkan produksi yang tinggi. Namun dilihat dari kadar karet kering (KKK) klon PB 260 masih menunjukkan KKK yang relatif lebih tinggi dibanding klon RRIM 600 dan PB 217. Dengan persentase kadar karet kering sebesar $38 \%$ pada frekuensi sadap d4, memberikan gambaran bahwa klon PB 260 mengalami hambatan aliran sehingga masih membutuhkan perangsang untuk mengurangi hambatan aliran tersebut.

Selain itu penurunan frekuensi sadap pada klon RRIM 600 dan PB 217 juga meningkatkan produksi, namun masih lebih rendah dibanding PB 260. Kandungan sukrosa dan fosfat anorganik untuk kedua klon tersebut masih pada level medium. Pelukaan pada klon RRIM 600 dan PB 217 tidak cukup untuk menggali potensi produksi pada kedua klon tersebut. Perlu alternatif lain untuk meningkatkan produksi pada klon tersebut, mengingat kondisi aktivitas metabolisme masih pada level di bawah optimum.

Ditinjau dari kesehatan tanaman, peningkatan frekuensi sadap meningkatkan risiko KAS pada klon PB 260 dan RRIM 600 (Tabel 1). Intensitas KAS pada PB 260 dan
RRIM 600 mencapai 75\% dan 50\% dengan penyadapan setiap hari. Klon dengan metabolisme tinggi maupun sedang memiliki risiko KAS yang tinggi dengan peningkatan frekuensi sadap dibanding klon dengan metabolisme rendah seperti PB 217.

\section{Pengaruh Frekuensi Stimulan}

Respons tiap klon terhadap stimulan menunjukkan perbedaan. Potensi peningkatan produksi dengan penggunaan stimulan bervariasi sesuai dengan kemampuan biosintesisnya. Penggunaan stimulan dengan frekuensi 12/y tidak mampu meningkatkan produksi klon $\mathrm{PB}$ 260 (Gambar 2). Klon PB 260 telah memiliki produksi yang tinggi tanpa stimulasi. Sementara klon RRIM 600 dan PB 217 respons terhadap stimulan. Klon RRIM 600 memiliki respons intermediate terhadap stimulasi, dengan maksimum frekuensi stimulan 12/y, dimana jika frekuensi stimulan ditingkatkan menjadi dua kali lipat tidak terjadi peningkatan produksi yang signifikan. Sementara klon PB 217 sangat respon terhadap stimulan, aplikasi stimulan 24/y tampak signifikan meningkatkan produksi.

Stimulasi tidak memberikan perbedaan yang nyata pada kandungan sukrosa ketiga klon tersebut. Peningkatan frekuensi stimulan sebanding dengan peningkatan kandungan fosfat anorganik. Kandungan fosfat anorganik dan tiol pada klon PB 260 secara signifikan lebih tinggi dibanding klon RRIM 600 dan PB 217 dengan peningkatan frekuensi stimulan.

Tanpa stimulasi, klon PB 260 telah menghasilkan produksi yang tinggi dengan kandungan fosfat anorganik yang tinggi dan kandungan sukrosa yang rendah. Hal ini

Tabel 1. Kategori kering alur sadap (KAS) pada berbagai frekuensi sadap Table 1. Category of tapping panel dryness at various tapping frequencies

\begin{tabular}{|c|c|c|c|}
\hline \multirow{2}{*}{$\begin{array}{l}\text { Perlakuan } \\
\text { Treatment }\end{array}$} & \multicolumn{3}{|c|}{$\begin{array}{l}\text { Klon } \\
\text { Clones }\end{array}$} \\
\hline & PB 260 & RRIM 600 & PB 217 \\
\hline $\mathrm{S} / 2 \mathrm{~d} 1$ & 3 & 2 & 1 \\
\hline $\mathrm{S} / 2 \mathrm{~d} 2$ & 1 & 2 & 1 \\
\hline $\mathrm{S} / 2 \mathrm{~d} 4$ & 1 & 1 & 1 \\
\hline
\end{tabular}

Kategori KAS (Category of dryness): $0 \%=0 ; 1-25 \%=1 ; 26-50 \%=2 ; 51-75 \%=3 ; 76-100 \%=4$ 

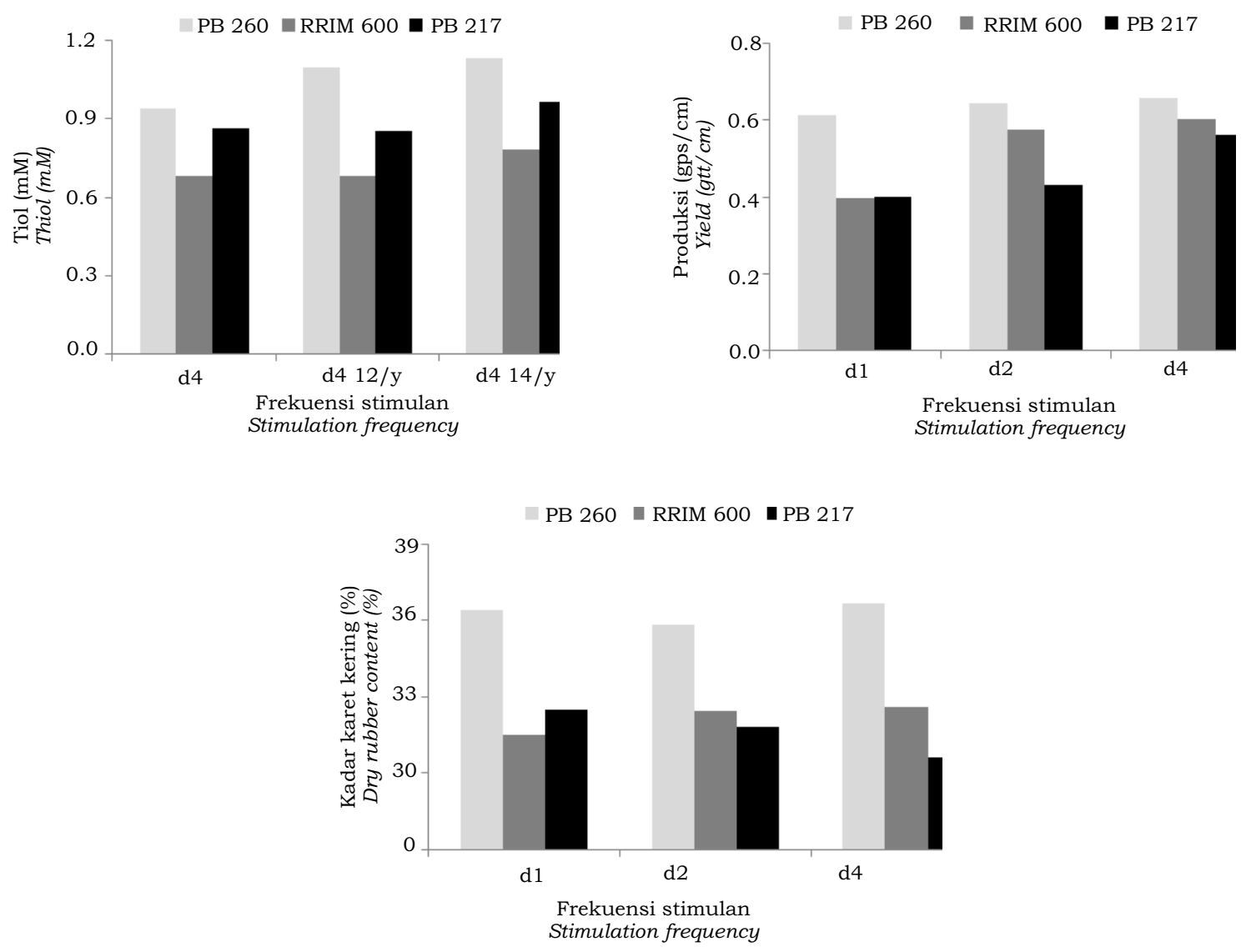

Gambar 2. Hubungan frekuensi stimulan dengan produksi dan parameter fisiologi pada klon PB 260, RRIM 600, dan PB 217

Figure 2. Relationship between stimulation frequencies and production as well as physiological parameters of PB 260, RRIM 600, and PB 217 clones

menandakan klon PB 260 tidak mengalami hambatan dalam regenerasi lateks. Kadar fosfat anorganik tampak sudah mencapai batas maksimum (tanpa stimulan) sehingga pemberian stimulan tidak mampu meningkatkan energi untuk sintesis lateks. Hal tersebut menggambarkan bahwa klon PB 260 telah mempunyai aktivitas metabolisme tinggi untuk menghasilkan produksi yang tinggi pada kondisi tanpa stimulan (Jacob et al., 1989), dan juga kadar sukrosanya rendah tanpa stimulan. Kadar sukrosa yang rendah pada PB 260 tidak mendukung dalam penggunaan stimulan. Namun klon PB 260 mengalami hambatan aliran yang ditunjukkan dengan KKK yang tinggi, sehingga masih dimungkinkan untuk pemberian stimulan dengan frekuensi stimulan yang rendah $(\leq 6 / y)$. Klon PB 260 termasuk klon metabolisme tinggi dengan sistem regenerasi lateks yang efisien dan distribusi asimilat yang baik untuk produksi lateks (Ao Shuochang dan Guo Yagang, 1990).

Tanpa stimulasi, klon RRIM 600 dan PB 217 memiliki produksi yang rendah dengan kandungan sukrosa medium dan kandungan fosfat anorganik yang rendah dibanding klon PB 260. Penggunaan stimulan mampu meningkatkan produksi RRIM 600 dan PB 217 dengan meningkatkan aktivitas metabolisme tanaman (Pi meningkat) dan meningkatkan konsumsi sukrosa. Hal tersebut menggambarkan peningkatan produksi lateks dengan stimulan akan tercapai pada kondisi metabolisme sel lateks yang masih rendah tanpa stimulan, yaitu ketika kandungan sukrosa medium-tinggi dan kandungan fosfat anorganik rendah. Stimulan mampu mempengaruhi sirkulasi asimilat, dengan meningkatkan penggunaan asimilat untuk produksi lateks (Silpi et al., 2006). 
Analisa penggunaan stimulan selain ditinjau dari aspek fisiologi dan produksi tanaman, juga dapat dikaitkan dengan kesehatan tanaman. Pemberian stimulan pada PB 260 mempunyai risiko KAS yang lebih tinggi sebesar 26-50\% dibandingkan dengan klon RRIM 600 dan PB 217 (Tabel 2). Metabolisme sel lateks pada klon metabolisme tinggi (seperti PB 260) sangat rentan terhadap stimulan, yang dapat berdampak negatif pada kesehatan tanaman (Vijayakumar et al., 1990; Lacote et al., 2010). Pemberian stimulan pada PB 260 hingga melebihi batas kemampuan tanaman akan memicu tidak berfungsinya sel lateks. Sementara RRIM 600 dan PB 217 termasuk klon metabolisme sedang dan rendah, dengan sifat responsif terhadap stimulan dan dalam jangka panjang penggunaan stimulan tidak memberikan efek negatif terhadap sel lateks (Lacote et al., 2010).

\section{KESIMPULAN DAN SARAN}

Klon berproduksi tinggi (quick starter) dengan kandungan sukrosa rendah dan fosfat anorganik tinggi seperti PB 260, hanya membutuhkan pelukaan (wounding) untuk mengaktifkan metabolisme sel lateks, tidak membutuhkan stimulan dengan frekuensi yang tinggi untuk meningkatkan produksi. Stimulan pada klon berproduksi tinggi hanya berfungsi untuk mengurangi adanya hambatan aliran. Selain itu, penggunaan stimulan pada PB 260 dalam jangka panjang dapat memberikan efek negatif terhadap kesehatan tanaman, antara lain kekeringan alur sadap. Semetara klon RRIM 600 dan PB 217 membutuhkan stimulan untuk mengaktifkan metabolisme sel lateks. Frekuensi optimal untuk RRIM 600 dan PB 217 masing-masing adalah $12 / y$ dan $24 / y$.

\section{DAFTAR PUSTAKA}

Shuochang, A., dan G. Yagang. 1990. Exploration of the high yield physiological regulation of the Hevea brasiliensis in Xishuangbanna. Proceedings of IRRDB symposium physiology and exploitation of Hevea brasiliensis. Kunming, China.
d'Auzac and J. L. Jacob. 1984. Physiology of the Laticiferus System in Hevea Basis and Application to Productivity. Compte-Rendu du Colloque : Exploitation and Physiology Amelioration. Perancis.

Dische, Z. M. 1962. Carbohydrate Chemistry. Vol.1. Academic Press.

Gohet, E., C. Scomparin, E. Cavaloc, Y. Balerin, G. Benites, F. Dumortier, H. Williams, H.P. Permadi, E. Ginting, E. De Rostolan, E. Uche, P. Chegbene, E. Hocepied, P. Echimane, M. Saumahoro, H. J. Sargeant, Suyatno; C. A. Najera, B. Saumahoro, R. lacote; and J. M. Eschbach. 2008. Influence of Ethephon Stimulation on Latex Physiological Parameter and Conquences on Latex Diagnosis Implementation in Rubber AgroIndustry. IRRDB Workshop : Latex Harvesting Technology.

Jacob, J. L., J. C. Prevot, D. Roussel, R. Lacrotte, E. Serres, J. dAuzac, J. M. Eschbach, dan H. Omont. 1989. Field limiting factors, latex physiological parameters, latex diagnosis, and clonal typology. In Physiology of Rubber Tree Latex.

Junaidi, U., A. Tjasadihardja, Kuswanhadi; dan Thomas. 1990. Tapping stimulation on the B0-1 panel of several recommended rubber clones. Proceeding of IRRDB Symphosium: Physiology and Exploitation of Hevea brasiliensis. October, 6-7.

Lacote, R., O. Gabla, S. Obouayeba, J. M. Eschbach, F. Rivano, K. Dian, dan E. Gohet. 2010. Long Term Effect of Ethylene Stimulation on the Yield of Rubber Trees is Linked to Latex Cell Biochemistry. Field Crops Research, 115: 94-98.

McMullen, A. I. 1960. Thiol of low moleculer weight in Hevea brasiliensis latex. Biochem. Biophys. Acta, 41, 152-154. 
Silpi, U., P. Thaler, P. Kasemsap, A. Lacointe, A. Chantuma, B. Adam, E. Gohet, S. Thanisawanyangkura, dan T. Ameglio. 2006. Effect of tapping activity on the dinamics of radial growth of Hevea brasiliensis trees. Tree Physiology 26: 1579-1587.

Taussky, H. H. dan E. Shorr. 1953. A micro colorimetric methods for the determination of inorganic phosphorus. J. Biol. Chem 202: 675685.
Tungngoen, K., P. Kongsawadworakul, U. Viboonjun, M. Katsuhara, N. Brunel, S. Sakr, J. Narangajavana, and $\mathrm{H}$. Chrestin. 2009. Involvement of HbP1P2;1 dan HbT1P1;1 aquaporins in ethylene stimulation of latec yield, through regulation of water exchanges between inner liber and latex cells in Hevea brasiliensis. Plant Physiology 151: 843-856.

Vijayakumar, K.R.; S. Sulochanamma; Molly Thomas; S. Sreelatha; Sheela P. Simon and M. R. Sethuraj. 1990. Proc. of IRRDB Symposium : Physiology and Exploitation of Hevea brasiliensis. Kunming, China. 